Communications in Information Literacy

Volume 11 | Issue 1

Article 18

7-12-2017

\title{
Book Review: Teaching Information Literacy Reframed: 50+ Framework-based Exercises for Creating Information Literate-Learners
}

Tish Hayes

Moraine Valley Community College, hayesL45@morainevalley.edu

Follow this and additional works at: https://pdxscholar.library.pdx.edu/comminfolit

Part of the Information Literacy Commons

Let us know how access to this document benefits you.

\section{Recommended Citation}

Hayes, T. (2017). Book Review: Teaching Information Literacy Reframed: 50+ Framework-based Exercises for Creating Information Literate-Learners. Communications in Information Literacy, 11 (1), 255-260. https://doi.org/10.15760/comminfolit.2017.11.1.50

This open access Book Review is distributed under the terms of the Creative Commons AttributionNonCommercial-ShareAlike 4.0 International License (CC BY-NC-SA 4.0). All documents in PDXScholar should meet accessibility standards. If we can make this document more accessible to you, contact our team. 


\section{Review of Teaching Information Literacy Reframed: 50+ Framework-Based Exercises for Creating Information-Literate Learners By Joanna M. Burkhardt}

Reviewed by Tish Hayes, Moraine Valley Community College

Keywords: book review; ACRL Framework; information literacy

\section{Book Reviews edited by Merinda McLure}

Hayes, T. (2017). Teaching Information Literacy Reframed: 50+ Framework-Based Exercises for Creating Information-Literate Learners by Joanna M. Burkhardt. Communications in Information Literacy, 11(1), 255-260.

Copyright for articles published in Communications in Information Literacy is retained by the author(s). Author(s) also extend to Communications in Information Literacy the right to redistribute this article via other scholarly resources and bibliographic databases. This extension allows the authors' copyrighted content to be included in some databases that are distributed and maintained by for-profit companies. All other rights of redistribution are licensed by Communications in Information Literacy under Creative Commons Attribution-NonCommercial-ShareAlike 4.0 International (CC BYNC-SA 4.0). 


\section{Review of Teaching Information Literacy Reframed: 50+ Framework-Based Exercises for Creating Information-Literate Learners By Joanna M. Burkhardt}

Many teaching librarians will be familiar with Joanna Burkhardt's Teaching Information Literacy (2003), which offered 35 "standards-based exercises for college students," as well as the second edition, Teaching Information Literacy: 50 Standards-Based Exercises for College Students (2010). Burkhardt co-authored both works with Mary C. MacDonald and Andrée J. Rathemacher and the 2010 edition included exercises that were contributed by additional colleagues. Teaching Information Literacy Reframed takes a similar approach and provides classroom exercises that are aligned with the Association of College and Research Libraries (ACRL) Framework for Information Literacy for Higher Education (2015). The book is a solo effort and I missed the voices of Burkhardt's prior co-authors and contributors. They represented different academic institutions and their contributions brought depth and unique perspectives to the text.

Burkhardt has structured this work around the Framework's six frames and in the first chapter, "Decoding the Framework for Information Literacy," she provides background information on the transition from the ACRL Information Literacy Competency Standards for Higher Education (2000) and the development of the Framework. As this chapter title suggests, Burkhardt presents the Framework as in need of interpretation or "decoding" (p. 1) and describes the frames as theoretical and difficult to interpret. She suggests that the Framework is a "philosophical rather than practical document" (p. 4) with which some librarians may struggle to engage, given limited time, energy, and institutional support ( $\mathrm{p}$. 5). Burkhardt's decision to address this may resonate with like-minded readers, as this past year's conversations about the Framework on the ACRLFRAME, ILI-L, and CJCLS listservs suggest that many librarians share this perspective and frustration. In this first chapter, Burkhardt also considers each frame and offers her brief interpretation of the Framework's key concepts. She gives significant attention to threshold concepts but could also have included an overview of essential questions and backwards design, as presented by Grant Wiggins and Jay McTighe in Understanding by Design (2005), and integrated Thomas P. Mackey and 
Trudi E. Jacobson's scholarship on metaliteracy (2013). The Framework references each of these directly.

In chapters two through seven, Burkhardt explores each frame and presents the more than 50 exercises that are noted in the book's subtitle and conveniently listed together at the beginning of the book. In each of these chapters she introduces one of the frames and uses this introduction to further "decode" (p. 1) the Framework. She also muses about the changing information landscape (online versus print resource access, for example), describes new ways in which students are engaging with research (such as through social media), and provides examples and some context for teaching librarians' use of the provided classroom exercises. Burkhardt might have strengthened these chapters by giving added attention to the knowledge practices and dispositions that are explored in the Framework and to teaching librarians' engagement with both as they develop learning outcomes and related assessment for local information literacy instruction. Readers may find it helpful to turn to Megan Oakleaf's practical article, "A Roadmap for Assessing Student Learning Using the New Framework for Information Literacy for Higher Education" (2014), for additional support and context when using the Framework to create lesson plans.

Burkhardt presents each included classroom exercise with accompanying, suggested learning outcomes; a sentence or two of directions for the teaching librarian; and instructions for students to carry out the activity, including discussion questions. Teaching librarians could use these questions for discussion or student reflection and they seem most appropriate for instruction with novice learners or first-year students. Many of the exercises could be integrated into a brief, one-shot session, while others might provide the focus of an entire class period and be used as course assignments implemented by a librarian and a primary course instructor. Burkhardt does not indicate the intended audience (e.g. first-year or graduate students) or possible disciplinary connections (e.g. business or writing) for each exercise and readers will need to undertake these considerations when selecting exercises for use in specific contexts. Burkhardt's organization of the exercises across chapters makes it difficult to see the ways in which the frames overlap and connect and how the learning outcomes for a single exercise might address multiple frames. An alternate chapter organization, or the addition of an exercise coding system, could improve subsequent editions. 
The book’s final chapter, "Creating Exercises, Rubrics, Learning Outcomes, and Learning Assessments," concludes the book while also encouraging readers to articulate clear expectations for student learning and to design instruction that attends to learners' existing knowledge and prior learning. This chapter also considers the design of learning outcomes and assessments, including rubrics. I felt that Burkhardt missed an opportunity in this chapter to provide readers with assessment examples to accompany her classroom exercises. References to helpful, relevant resources, such as the classic Classroom Assessment Techniques (Angelo \& Cross, 1993) and the more recent Classroom Assessment Techniques for Librarians (Bowles-Terry \& Kvenild, 2015) would have been useful additions.

While many librarians may be just beginning to work with the Framework, others have already examined its theoretical foundations (Foasberg, 2015; Kuglitsch, 2015; Pagowsky, 2015), explored using the Framework when collaborating with faculty and initiating dialogues across disciplines (Garcia, 2014; Knapp \& Brower, 2014), and developed related classroom activities (Seeber, 2015). Burkhardt may have conceived of this book before she could fully engage with the early flurry of activity that has followed the Framework's development and official adoption by ACRL. Instruction librarians might consider supplementing the exercises that are included in this book by seeking out Framework-based exercises shared by colleagues on active listservs, at conferences, in Webinars presented by the ACRL Instruction Section and the ACRL Student Learning and Information Literacy Committee, and through shared resources such as the Community of Online Research Assignments (CORA) < https://www.projectcora.org/> and the ACRL Framework for Information Literacy Sandbox < http://sandbox.acrl.org/ $>$.

Published: Chicago, IL: Neal-Schuman, an imprint of the American Library Association, 2016

\section{References}

Angelo, T. A., \& Cross, K. P. (1993). Classroom assessment techniques: A handbook for college teachers (2nd ed.). San Francisco, CA: Jossey-Bass.

Association of College \& Research Libraries. (2000). Information literacy competency standards for higher education. Retrieved from http://www.ala.org/acrl/standards/informationliteracycompetency 
Association of College \& Research Libraries. (2015). Framework for information literacy for higher education. Retrieved from http://www.ala.org/acrl/standards/ilframework

Bowles-Terry, M., \& Kvenild, C. (2015). Classroom assessment techniques for librarians. Chicago, IL: Association of College and Research Libraries.

Burkhardt, J. M., MacDonald, M. C., \& Rathemacher, A. J. (2003). Teaching information literacy. Chicago, IL: American Library Association.

Burkhardt, J. M., MacDonald, M. C., \& Rathemacher, A. J. (2010). Teaching information literacy: 50 Standards-based exercises for college students (2nd ed.). Chicago, IL: American Library Association.

Foasberg, N. M. (2015). From standards to frameworks for IL: How the ACRL Framework addresses critiques of the Standards. portal: Libraries and the Academy, 15(4), 699-717.

Garcia, L. (2014). Applying the Framework for Information Literacy to the developmental education classroom. Community \& Junior College Libraries, 20(1-2), 39-47. http://dx.doi.org/10.1080/02763915.2014.1013399

Jacobson, T. E., \& Mackey, T. P. (2013). Proposing a metaliteracy model to redefine information literacy. Communications in Information Literacy, 7(2), 84-91.

Knapp, M., \& Brower, S. (2014). The ACRL Framework for Information Literacy in Higher Education: Implications for health sciences librarianship. Medical Reference Services Quarterly, 33(4), 460-468. http://dx.doi.org/10.1080/02763869.2014.957098

Kuglitsch, R. Z. (2015) Teaching for transfer: Reconciling the Framework with disciplinary information literacy. portal: Libraries and the Academy, 15(3), 457-470.

Oakleaf, M. (2014). A roadmap for assessing student learning using the new Framework for Information Literacy for Higher Education. The Journal of Academic Librarianship, 40(5), 510-514. http://dx.doi.org/10.1016/j.acalib.2014.08.001

Pagowsky, N. (2015). A pedagogy of inquiry. Communications in Information Literacy, 9(2), 136-144.

Seeber, K. P. (2015). Teaching "format as a process" in an era of Web-scale discovery. Reference Services Review, 43(1), 19-30. http://dx.doi.org/10.1108/RSR-07-2014-0023 
Wiggins, G., \& McTighe, J. (2005). Understanding by design (Expanded, 2nd ed.). Alexandria, VA: Association for Supervision and Curriculum Development. 